\title{
Rozwój zrównoważony, postwzrost, dobre życie (Buen Vivir). Głosy z Ameryki kacińskiej i Hiszpanii
}

\author{
Bogumiła Lisocka-Jaegermann \\ Ośrodek Studiów Amerykańskich, Uniwersytet Warszawski \\ al. Niepodległości 22, 02-653 Warszawa \\ bjlisock@uw.edu.pl• ORCID: 0000-0002-3956-0369
}

\section{Streszczenie}

Pierwsza część tekstu dotyczy z jednej strony krytycznych ujęć „rozwoju”, z drugiej zaś niespójności i sprzeczności w oficjalnych, instytucjonalnych konceptualizacjach rozwoju zrównoważonego, na które wskazują liczni przedstawiciele nurtów krytycznych. Druga część poświęcona jest próbom wpisywania „zrównoważenia/trwałości” (sustainability) w dyskurs krytyczny.

Zasadniczą tezą jest wskazanie różnic między wizją „miękkiego zrównoważenia” mieszczącą się w oficjalnym nurcie i wizjami zrównoważenia "twardego" i "bardzo twardego" wpisanymi w nurty krytyczne, w tym radykalne ujęcia biocentryczne i dekolonialne. Tezę towarzyszącą stanowi stwierdzenie o znaczeniu kontekstów, w jakich powstają i funkcjonują wymienione powyżej dyskursy krytyczne ze wskazaniem na latynoamerykańskie przykłady inicjatyw transformacyjnych.

\section{Słowa klucze}

krytyka rozwoju, rozwój zrównoważony/trwały, postwzrost, trwały postwzrost, inicjatywy transformacji

\section{Wprowadzenie}

Niniejszy tekst stanowi zwięzłe podsumowanie debat toczących się wokół koncepcji rozwoju zrównoważonego w kontekście nasilającej się krytyki pojęcia „rozwój”. Autorka odwołuje się przede wszystkim, choć nie wyłącznie, do głosów naukowców i działaczy społecznych pochodzących z krajów hiszpańskojęzycznych. Ich poglądy wyrastają z trudnych doświadczeń krajów latynoamerykańskich, które wkroczyły na ścieżkę neoliberalnego rozwoju gospodarczego pod koniec dekady lat 8o. XX w. zdominowanej przez kryzys zadłużeniowy. Dążenie do przyspieszenia tempa rozwoju gospodarczego i do ograniczenia zasięgu ubóstwa przełożyło się na intensyfikowanie eksploatacji zasobów przyrodniczych - przede wszystkim kopalin. Koncepcja „rozwoju zrównoważonego” czy "trwałego” (hiszp. desarrollo sostenible), obecna w dyskursie publicznym i w deklaracjach polityków i przedstawicieli władz państwowych, zderza się w Ameryce Łacińskiej z rzeczywistością: wielkoskalowe górnictwo i wielkoobszarowe intensywne uprawy roślin przeznaczonych na eksport, takich jak soja, powodują nieodwracalne szkody 
w środowisku przyrodniczym i stanowią zagrożenie dla egzystencji społeczności lokalnych. Taka sytuacja skłania zarówno naukowców, jak i społeczników do krytycznych ocen dominującego modelu rozwoju i do kwestionowania rozwiązań określanych jako działania zgodne z założeniami rozwoju zrównoważonego. Sprzyja także poszukiwaniom alternatywnych scenariuszy zmian, takich jak głośna już koncepcja "dobrego życia” (Buen Vivir), nawiązująca do kulturowych i społecznych tradycji andyjskich. Sprawia też, że alternatywne koncepcje "rozwoju” formułowane w innych częściach świata wzbudzają zainteresowanie i traktowane są poważnie. Dlatego też żywy jest dialog między badaczami i działaczami latynoamerykańskimi i hiszpańskimi. Prace tych ostatnich wyrastają przede wszystkim z kontekstu iberyjskiego: napięć, jakie towarzyszyły przyspieszonemu rozwojowi gospodarczemu Hiszpanii po przystąpieniu tego kraju do Unii Europejskiej, oraz z dramatycznego kryzysu, który dotknął kraj w latach 2008-2013. Zarówno alternatywne scenariusze zmian społecznych i gospodarczych formułowane przez badaczy, jak i te, które rodzą się w społecznościach lokalnych, określane są coraz częściej jako inicjatywy transformacyjne. W niniejszym tekście chcę przedstawić szersze tło ich rosnącego znaczenia.

Warto podkreślić, że w latynoamerykańskich dyskusjach wokół „rozwoju” i „alternatyw dla rozwoju" widoczne są silne wpływy ekologii politycznej. Ten nurt badań wskazuje, że środowisko, w którym żyjemy, w znacznym stopniu ukształtowane jest przez procesy polityczne i społeczne. Ich znaczenie dla przekształceń środowiska w krajach doświadczonych dominacją kolonialną jest szczególnie wyraźne (Bryant, Bailey 1997). Postrzeganie przyrody przez kolonialistów było odmienne od jej wizerunku wśród skolonizowanych. Tworzenie i podtrzymywanie oficjalnych wyobrażeń przyrody jest procesem o charakterze politycznym, mocno powiązanym z kontekstem społeczno-gospodarczym (Escobar 1999).
Dlatego też studia nad powiązaniami pomiędzy sferą zjawisk społeczno-gospodarczych, polityką i środowiskiem dotyczą zarówno relacji między różnymi aktorami społecznymi a środowiskiem, jak i rzeczywistych efektów środowiskowych polityki gospodarczej (Peet, Watts 2004). Leżące u podstaw decyzji politycznych i gospodarczych idee i odpowiadające im pojęcia, takie jak „rozwój”, czy „rozwój zrównoważony”, stają się przedmiotem krytycznej refleksji, uwzględniającej ich historię, wpisywane w nie znaczenia, a także następstwa ich popularności.

Uczestnikami relacjonowanych debat są przede wszystkim przedstawiciele nauk humanistycznych i społecznych, takich jak antropologia, filozofia, socjologia czy geografia społeczno-ekonomiczna oraz przyrodnicy. W mniejszym stopniu biorą w nich udział ekonomiści. Rysem charakterystycznym działań pracowników akademickich, o których mowa, jest często pojawiająca się, bliska współpraca z działaczami społecznymi reprezentującymi zarówno inicjatywy lokalne, jak i szerokie ruchy społeczne obecne w latynoamerykańskim życiu społecznym i politycznym od lat 9o. dwudziestego wieku.

\section{Od krytyki pojęcia „rozwoju" po krytykę koncepcji "rozwoju zrównoważonego"}

Pojęcie „rozwoju” weszło na stałe do słownika polityków i naukowców pod koniec lat 40. XX w. ${ }^{1}$. Jak zauważa Wolfgang Sachs, redaktor jednej z pierwszych, głośnych książek poświęconych jego krytyce: „Rozwój to znacznie więcej niż przedsięwzięcie społeczno-gospodarcze; to także model percepcji kształtujący rzeczywistość, mit pocieszający społeczeństwa, fantazja budząca namiętności” (Sachs 1992: 1). „Rozwój” stał się częścią wyobrażeń zbiorowych. Podział świata na kraje wysoko rozwinięte i kraje słabo rozwinięte do dziś jest jedną

1 Na ogół przyjmuje się, że na arenie polityki międzynarodowej, po raz pierwszy kategoriami „rozwoju” i „krajów słabo rozwiniętych” posłużył się prezydent Stanów Zjednoczonych, Harry Truman, w swoim przemówieniu inauguracyjnym wygłoszonym w styczniu $1949 \mathrm{r}$. 
z najbardziej rozpowszechnionych konceptualizacji różnic globalnych. Teorie, programy i projekty rozwojowe od lat 6o. były ważnym, o ile nie najważniejszym elementem relacji między krajami rozwiniętymi i tak zwanym Trzecim Światem. Oficjalny, instytucjonalny dyskurs rozwojowy rozwijany przez instytucje międzynarodowe, przez rządowe i pozarządowe agencje rozwojowe splótł się z działaniami wpisanymi w pomoc rozwojową, określaną teraz jako międzynarodowa współpraca na rzecz rozwoju. Rozwój pojmowany był w ich obrębie zgodnie z paradygmatem modernizacyjnym, który w myśleniu potocznym utożsamiany jest wręcz z rozwojem, co odzwierciedlają na przykład popularne definicje słownikowe $^{2}$. Pierwszym istotnym zwrotem $w$ takim myśleniu o rozwoju były teorie rozwoju zależnego, które pojawiły się w kręgu Komisji ONZ do spraw Ameryki Łacińskiej i Karaibów. Zakwestionowały one założenie, że receptą na rozwój jest przyspieszone podążanie ścieżką wyznaczoną przez historyczną trajektorię krajów uprzemysłowionych. Za przyczynę "niedorozwoju” uznano bowiem historyczne uzależnienie peryferii od centrum, wskazując na zerwanie więzów zależności jako na warunek do osiągnięcia pożądanych celów „rozwojowych". Pojawiające się w różnych środowiskach głosy krytyczne, inspirowane zarówno wynikami badań naukowych, jak i często jaskrawymi przykładami niepowodzeń projektów rozwojowych, realizowanych zgodnie z założeniami modernizacji, osiągnęły kulminację w latach 9o. XX w. Krytyka koncepcji i praktyk rozwojowych dotyczyła ich różnych aspektów: zwracano uwagę, między innymi, na stosowanie tych samych rozwiązań w społecznościach odmiennych pod względem kulturowym, społecznym, gospodarczym i środowiskowym, na pomijanie głosów społeczności lokalnych, które

2 Na przykład Stownik Języka Polskiego, pod redakcją Mieczysława Szymczaka, definiuje rozwój jako „proces przeobrażeń, zmian przechodzenia do stanów lub form bardziej złożonych, lub pod pewnym względem doskonalszych". miały być beneficjentami inicjatyw rozwojowych, na nieuwzględnianie odmiennego statusu społecznego kobiet i mężczyzn (Lisocka-Jaegermann 2011), na przedmiotowe traktowanie instytucji krajów przyjmujących pomoc rozwojową. W ujęciu radykalnym, dostrzeżono w dyskursie rozwoju mechanizm dominacji, który zastąpił więzy zależności kolonialnej. Innymi słowy, uważano, że Zachód stworzył Trzeci Świat, by móc nadal kontrolować niepodległe kraje globalnego Południa. Taki pogląd zyskał wielu zwolenników w środowiskach, w których nadal bardzo żywe były idee wspomnianej powyżej szkoły zależności. Przyczyniła się do tego w dużym stopniu głośna książka Arturo Escobara, pochodzącego z Kolumbii antropologa pracującego na uniwersytetach północnoamerykańskich i publikującego swe prace także po hiszpańsku (Escobar 1995), która zyskała ogromną popularność w krajach latynoamerykańskich.

Słowo „rozwój” - bez względu na doprecyzowujące je przymiotniki, czy inne określenia odwołujące się do jego konkretnego wymiaru, takie jak: rozwój lokalny, endogenny, partycypacyjny, etnorozwój, oraz także rozwój zrównoważony - traktowane jest w krajach latynoamerykańskich ze znacznie większą rezerwą niż w Europie czy Stanach Zjednoczonych. Dlatego też są badacze wyraźnie odróżniający „rozwój alternatywny”, czy „alternatywy rozwojowe” od „alternatyw dla rozwoju”. Te pierwsze mieszczą się w paradygmacie modernizacji i podporządkowane są ideologii postępu. Obejmują zarówno rozwiązania mające na celu korygowanie negatywnych następstw działań rozwojowych, jak i te, które wbudowują w koncepcję rozwoju niedostatecznie obecne w niej wymiary: społeczny (walka z ubóstwem, rozwój społeczny), politycznogospodarczy (wspomniana już szkoła rozwoju zależnego) i środowiskowy (ekorozwój) (Gudynas 2011). Te drugie, czyli alternatywy rozwojowe obejmują postulat całkowitego odejścia od pojęcia „rozwoju”. Jego zwolennicy argumentują go zbyt dużym obciążeniem pojęcia „rozwój” historycznym 
bagażem znaczeń wpisanych w dominację metropolii nad koloniami, Zachodu nad Południem, organizacji międzynarodowych i rządów nad społecznościami lokalnymi. Proponowane alternatywne scenariusze przyszłości to między innymi Buen Vivir (dobre życie) ${ }^{3}$, postwzrost i inne rozwiązania o wysokim stopniu zrównoważenia/trwałości, wychodzące poza dominujący paradygmat rozwoju społeczno-gospodarczego.

Ekorozwój i rozwój zrównoważony to koncepcje uważnie śledzone i żywo komentowane w Ameryce Łacińskiej od momentu ich narodzin, a zwłaszcza od czasu, gdy koncepcję ekorozwoju ${ }^{4}$, po konferencji w Sztokholmie w 1972 r. zdecydowano się przemianować na rozwój zrównoważony/ trwały ${ }^{5}$. Nowe sformułowanie nie eliminowało sprzeczności i wątpliwości wpisanych w sam termin „rozwój” i jest to istotny aspekt krytyki rozwoju zrównoważonego w regionie. Oprócz wymienionych już zastrzeżeń zgłaszanych pod adresem koncepcji rozwoju, takich jak na przykład zarzut, że dominujący dyskurs, za którym stoją potężne instytucje, „wymusza” takie same rozwiązania na krajach i społecznościach

$3 \mathrm{Z}$ racji tego, że latynoamerykańska koncepcja „dobrego życia” nawiązująca do tradycji społeczności andyjskich różni się od idei dobrostanu, będę posługiwała się w tekście jej oryginalną nazwą Buen Vivir.

4 O narodzinach koncepcji pisze sugestywnie uczestnik większości związanych z nimi wydarzeń, Ignacy Sachs w książce: Trzeci brzeg. W poszukiwaniu ekorozwoju, Wydawnictwo UW, Warszawa 2011. Ignacy Sachs był bardzo dobrze znany w Ameryce Łacińskiej - pracował przez wiele lat w Brazylii.

5 Anglojęzyczne sformułowanie „sustainable development" nie nastręcza trudności w tłumaczeniu na język hiszpański, ale niełatwo jednoznacznie przełożyć je na niektóre inne języki; przyjęty już polski odpowiednik „rozwój zrównoważony” nie odzwierciedla w pełni jego znaczenia, ale uważam, że jego umowne używanie w rozumieniu „zrównoważony/trwały" jest lepszym wyjściem niż pojawiający się ostatnio neologizm "sustensywny”. Niemiecka rada ekspertów do spraw środowiska proponuje posługiwanie się określeniem „rozwój trwale bezpieczny dla środowiska". funkcjonujących w skrajnie odmiennych warunkach, w Ameryce Łacińskiej najczęściej powtarzano opinię o nieokreśloności znaczenia pojęcia rozwoju zrównoważonego/trwałego i o tym, że jest używane dość dowolnie przez różne podmioty. Lista zastrzeżeń wobec koncepcji jest długa i dobrze znana (Lisocka-Jaegermann, 2015: 13-20; 2017: 63-73; 2018: 21-31). W warunkach latynoamerykańskich mocno brzmią tezy przedstawiane w Polsce przez Wiesława Sztumskiego (Sztumski 2006: 73-76; 2008: 133-139; 2009: 13-23). „Być może, pod przykrywką wzniosłej idei kryje się perfidnie zamaskowana dla szerokich rzesz społecznych ordynarna żądza imperialna do sprawowania władzy globalnej przez garstkę możnych tego świata. Może chodzi po prostu o to, by obecnie panujące mafie i monopole gospodarcze i polityczne mogły zapewnić sobie niepodzielne, bezkrytyczne i bezkarne panowanie dzięki celowemu łudzeniu ludzi obietnicami na przyszłość bez pokrycia?" (Sztumski 2006: 73-76). Naukowcy współpracujący z ruchami społecznymi stającymi w obronie społeczności dotkniętych państwowymi politykami rozwojowymi, deklaratywnie zgodnymi z zasadami rozwoju zrównoważonego, mają wiele argumentów przemawiających za takim poglądem.

Autorzy książki Alternatywne przyrody. Nowe myślenie o przyrodzie i społeczeństwie (Macnaghten, Urry 2005) zwracaja uwagę na to, że globalny dyskurs zrównoważonego rozwoju opiera się na trzech przesłankach:

- po pierwsze, na koncepcji przyrody wpisującej się w doktrynę „realizmu środowiskowego", czyli na traktowaniu jej jako zespół zagadnień identyfikowanych na drodze nowoczesnych badań naukowych,

- $\quad$ po drugie, na traktowaniu człowieka jako istoty „racjonalnie” reagującej na dostarczone informacje i podejmującej adekwatne do nich działania,

- po trzecie, na założeniu, że ludzie mają poczucie sprawstwa i wierzą, że mają rzeczywisty wpływ na swoją 
sytuację i sytuację ich szerszego otoczenia.

Wszystkie trzy przesłanki mogą budzić w Ameryce Łacińskiej poważne wątpliwości. W społecznościach tubylczych, w wiejskich, metyskich społecznościach lokalnych funkcjonują wciąż odmienne od "zachodnich" koncepcje przyrody. Zachodni racjonalizm nie wyczerpuje motywów działań ludzkich tam, gdzie system wartości odwołuje się do interesów wspólnotowych, a nie indywidualnych. Poczucie sprawstwa wspólnot lokalnych w warunkach bezpardonowej walki kapitału wspieranego przez państwo o zyski jest bardzo ograniczone.

Argumentów krytycznych dostarczają także dokumenty i naukowe publikacje funkcjonujące w obiegu międzynarodowym. W jednym z raportów Międzynarodowej Unii Ochrony Przyrody czytamy o rozwoju zrównoważonym: „Pojęcie holistyczne, atrakcyjne i elastyczne, ale nieprecyzyjne. Idea rozwoju zrównoważonego może łączyć ludzi, ale niekoniecznie pomaga w uzgodnieniu wspólnych, konkretnych celów działania. Ponieważ rozwój zrównoważony może mieć tyle różnych znaczeń, w gruncie rzeczy pojęcie to nie oznacza nic" (Adams 2006); w jednym z tekstów naukowych: „nieprecyzyjne, wieloznaczne; każdy może je wykorzystywać według własnych potrzeb; «buzzword»" (Bonevac 2010: 84-101). Serge Latouche pisze wręcz, że wyrażenie „rozwój zrównoważony/trwały” jest oksymoronem, bo mówimy o rozwoju opartym na wzroście, a ten nie może być trwały; posługiwanie się nim przez instytucje rozwojowe i przez rządy to perwersja; pojęcie stało się, jego zdaniem, elementem retoryki chroniącej interesy świata zachodniego i neoliberalnej gospodarki podporządkowującej zasoby interesom gospodarczym (Latouche 2009b). Jeden ze znanych geografów brytyjskich pisze, że wszechobecność odwołań do rozwoju zrównoważonego odsuwa na bok krytykę hegemonicznego systemu i „odpolitycznia” debatę wokół problemów środowiskowych (Swyngedouw 2014).
Ignacy Sachs, uczestniczący w międzynarodowych inicjatywach budujących koncepcję rozwoju zrównoważonego, w których opowiadał się za sformułowaniem „rozwój trwały” (durable), pod koniec swego życia, pracując w Brazylii, posługiwał się konceptem ekosocjoekonomii (ecosocioeconomía), umożliwiającym odejście od pojęcia „rozwoju" przy uwzględnieniu zrównoważenia/ trwałości.

Warto odnotować, że oryginalna definicja wypracowana w Sztokholmie, według której rozwój zrównoważony/trwały to jest taki rozwój, w którym potrzeby obecnego pokolenia mogą być zaspokojone bez umniejszania szans przyszłych pokoleń na ich zaspokojenie (World Commission... 1987), kładąca nacisk na roztropne korzystanie z zasobów i trwałość rozwoju, w latynoamerykańskich dyskursach publicznych, a także w praktyce akademickiej, czego doświadczyłam, zastępowana jest przez ujęcie reprezentowane przez znany diagram składający się z trzech nachodzących na siebie okręgów, odzwierciedlający proces integrowania działań gospodarczych i społecznych, z zachowaniem równowagi przyrodniczej. Ograniczanie się do bliżej niesprecyzowanej „równowagi” ułatwia dowolne wykorzystywanie pojęcia rozwoju zrównoważonego.

Nic więc dziwnego, że Encyklika papieska Laudato si miała w krajach latynoamerykańskich silny oddźwięk - odwoływała się do doświadczeń bliskich Latynoamerykanom. Znalazły się w niej m.in. następujące stwierdzenia: „musimy przekształcić model globalnego rozwoju [...]. Często w kontekście rozwijającej się gospodarki rzeczywista jakość życia ludzi się obniża [...]. W tym kontekście mówienie o zrównoważonym rozwoju często nie tylko służy odwracaniu uwagi i usprawiedliwianiu, ale też zawłaszcza wartości dyskursu ekologicznego w obrębie logiki finansów i technokracji. Odpowiedzialność społeczna i ekologiczna przedsiębiorstw sprowadza się wówczas do serii działań marketingowych mających tworzyć korzystny obraz firm" (Franciszek 2016). 
Obok wysuwanych zarzutów dostrzegane są także niekwestionowane wartości rozwoju zrównoważonego/trwałego i prowadzone są próby dialogu z koncepcjami wypracowywanymi na arenie międzynarodowej. Stał się on uznawaną na świecie zasadą, podstawą strategii globalnych, takich jak Międzynarodowe Cele Rozwoju Zrównoważonego uchwalone w 2015 r. W wymiarze regionalnym wskazano na kluczową rolę nierówności społecznych stanowiących najważniejszą barierę realizacji celów w Ameryce Łacińskiej (Barcena 2016). Termin, który zyskał uznanie społeczne powinien być traktowany jako „pojęcie graniczne” (boundary term) „umożliwiające wzajemne kontakty między nauką i polityką" (Scoones 2010: 152-162), co ma pewną wartość, mimo niebezpieczeństw, jakie się z tym wiążą. Mimo zastrzeżeń, trzeba pamiętać, że pojęcie wskazuje na problem, na dalekosiężne cele, skłania do poszukiwania rozwiązań oraz wskaźników ilościowych pozwalających ocenić postęp na drodze realizacji celów.

O jednej ze strategii traktowania pojęcia rozwoju zrównoważonego w Ameryce Łacińskiej wspomniałam już, przytaczając koncepcję Ignacego Sachsa. Polega na pozostaniu przy „zrównoważeniu/trwałości” przy eliminacji składowej „rozwój”. Tyle, że samo „zrównoważenie/trwałość” jest też doprecyzowane określeniem jego natężenia (tabela 1).

Silne/twarde zrównoważenie/trwałość nie oznacza jedynie komplementarności i wzajemnej zastępowalności kapitałów: społecznego, ekonomicznego i środowiskowego. Przekłada się na odmienne sformułowane cele zmian (już nie wzrost i dobrostan społeczny, ale przede wszystkim jakość życia i jakość środowiska), zmianę wizji przyrody (z antropocentrycznej na biocentryczną), zmianę sposobu myślenia o wiedzy (poszanowanie dla wiedzy tubylczej, lokalnej przy odejściu od dominacji wiedzy naukowej), a więc głęboką transformację społeczną i gospodarczą. W ujęciach radykalnych oznacza to odejście od gospodarki rynkowej - postulowane wprost przez niektóre latynoamerykańskie ruchy społeczne i praktykowane w mikroskali w środowiskach lokalnych. W ujęciu bardziej umiarkowanym chodzi o głębokie zmiany w obrębie gospodarki rynkowej. Dostępny już w Polsce podręcznik ekonomii zrównoważonego rozwoju (Rogal 2010) odrzuca czystą gospodarkę rynkową jako wizję przyszłości, postulując stanowienie przez państwa „ram porządkowych ze zrównoważonymi (społeczno- ekologicznymi) barierami ochronnymi, wprowadzającymi w życie zasady sprawiedliwości wewnątrzpokoleniowej i międzypokoleniowej" (Rogal 2010: 544). Sprawiedliwość wewnątrzpokoleniowa i międzypokoleniowa oraz odpowiedzialność uważane są przez Autora cytowanej pracy za podstawę etyki zrównoważonego rozwoju rozpoznawanej jako istotny element gospodarowania zgodnie z jego zasadami. Postulaty odchodzenia od logiki klasycznej gospodarki kapitalistycznej znalazły też odzwierciedlenie w cytowanej już encyklice papieskiej: „Musimy być jednak przekonani, że spowolnienie pewnego tempa produkcji i konsumpcji może prowadzić do innego rodzaju postępu i rozwoju" (Franciszek 2016). O przeformułowaniu kapitalizmu jako o warunku przejścia do zrównoważonej gospodarki pisze obszernie Tim Jackson, autor raportu komisji Unii Europejskiej na rzecz zrównoważonego rozwoju z 2003 r. zatytułowanego Redefining Prosperity, na którym oparł późniejszą, głośną książkę dostępną także w języku polskim (Jackson 2015). Jackson wymienia takie elementy procesu przechodzenia do gospodarki zrównoważonej, jak opracowanie makroekonomii ekologicznej: zasad funkcjonowania gospodarki w warunkach ścisłego ograniczenia dostępności zasobów, a także emisji; inwestycje ekologiczne w pracę, infrastrukturę i aktywa; zwiększenie roztropności finansowej i fiskalnej oraz zmiana wskaźników gospodarczych uwzględniająca rozszerzoną, poza czynniki czysto gospodarcze, koncepcję dobrobytu. Z elementami ekonomicznymi ściśle sprzężona jest zmiana logiki funkcjonowania społeczeństwa: polityka regulowania czasu pracy, zmniejszanie nierówności 
Tabela 1. Trzy sposoby rozumienia wymiarów „zrównoważenia/trwałości” (sustainability) według Eduardo Gudynasa

\begin{tabular}{|c|c|c|c|}
\hline & „"słabe" / "miękkie" & "silne" I "twarde" & "bardzo silne" I "bardzo twarde" \\
\hline rozwój & $\begin{array}{l}\text { wzrost w wymiarze } \\
\text { materialnym }\end{array}$ & $\begin{array}{l}\text { wzrost w wymiarze materialnym } \\
\text { i dobrostan społeczny }\end{array}$ & jakość życia; jakość środowiska \\
\hline przyroda & $\begin{array}{l}\text { kapitał przyrodniczy - } \\
\text { zasoby }\end{array}$ & $\begin{array}{l}\text { kapitał przyrodniczy - zasoby } \\
\text { (problem wyczerpywania) }\end{array}$ & dziedzictwo przyrodnicze \\
\hline wartości & traktowane instrumentalnie & $\begin{array}{l}\text { instrumentalnie } \\
\text { z uwzględnieniem kwestii } \\
\text { ekologicznych }\end{array}$ & $\begin{array}{l}\text { wielość wartości } \\
\text { humanistycznych }\end{array}$ \\
\hline wizja przyrody & antropocentryczna & antropocentryczna & biocentryczna \\
\hline $\begin{array}{l}\text { sprawiedliwość } \\
\text { a środowisko }\end{array}$ & $\begin{array}{l}\text { ekonomiczna kompensacja } \\
\text { szkód srodowiskowych }\end{array}$ & sprawiedliwość środowiskowa & $\begin{array}{l}\text { sprawiedliwość środowiskowa; } \\
\text { sprawiedliwość ekologiczna }\end{array}$ \\
\hline aktorzy & konsumenci & konsumenci/obywatele & obywatele \\
\hline scena & rynek & społeczeństwo & społeczeństwo \\
\hline wiedza naukowa & pozycja uprzywilejowana & pozycja uprzywilejowana & wielość wiedzy \\
\hline inne rodzaje wiedzy & pomijane & $\begin{array}{l}\text { minimalizowane pod } \\
\text { względem znaczenia }\end{array}$ & włączane, szanowane \\
\hline działania praktyczne & zarządzanie techniczne & $\begin{array}{l}\text { zarządzanie techniczne } \\
\text { z konsultacjami }\end{array}$ & polityka środowiskowa \\
\hline
\end{tabular}

Źródło: adaptacja według: Eduardo Gudynas, Desarrollo y sustentabilidad ambiental: diversidad de posturas, tensiones permanentes, en: Mataran Ruiz A., López Catellano F., La Tierra no es muda: dialogos entre el desarrollo sostenible y el postdesarollo, Universidad de Granada, Granada s. 69-96.

strukturalnych, wzmacnianie kapitału społecznego, czy wreszcie dekonstrukcja kultury konsumpcjonizmu (Jackson 2015: 207-223). Rozdział poświęcony przejściu do zrównoważonej gospodarki kończy się fragmentem zatytułowanym To nie utopia (Jackson 2015:223). Konkretne przykłady,zrównoważonych/trwałych" przedsięwzięć mających na celu „dobro wspólne”, a nie wzrost, czy generowanie maksymalnych zysków, rozwijane w krajach niemieckojęzycznych Europy, podaje znany niemiecki psycholog społeczny, Harald Welzer (Welzer 2016). Należą do nich m.in. banki finansujące jedynie inicjatywy o charakterze zrównoważonym, ruch zrzeszający wspierające się wzajemnie przedsiębiorstwa ukierunkowane na dobro wspólne, zakłady energetyczne produkujące energię ze źródeł odnawialnych i aktywnie promujące rozwój takiego modelu energetyki, zrównoważona firma wytwórcza produkująca obuwie i meble.

\section{Koncepcja postwzrostu}

Najpełniejszym ucieleśnieniem idei przedstawionych powyżej zdaje się być koncepcja postwzrostu 6 . Postwzrost definiowany jest na ogół jako „zredukowanie poziomu produkcji i konsumpcji prowadzące do zwiększenia dobrostanu ludzi i poprawy warunków środowiskowych, zarówno w wymiarze lokalnym, jak i globalnym, w krótkiej, jak i długiej perspektywie czasowej" (Schneider et al 2010: 511-518). Zadanie to wiąże się

6 Pojęcie jest najczęściej używane w wersji anglojęzycznej: degrowth, hiszpańskojęzycznej: decrecimiento, francuskojęzycznej: decroissance, czy włoskiej: decrescita. 
z przebudowaniem modelu gospodarki i radykalnymi zmianami stylu życia, ze „zmianą kultury i ponownym odkryciem ludzkiej tożsamości w oderwaniu od wizji rynku" (Demaria 2013: 191-215). Postwzrost odrzuca logikę rynku i kulturę konsumpcyjną jako centralną zasadę organizującą życie.

Termin ma już dość długą historię, a - według redaktorów słownika terminów związanych z tym pojęciem (D’Alisa et al 2015) - został użyty po raz pierwszy w wersji francuskiej (décroissance) w 1972 r. przez francuskiego intelektualistę André Gorz'a (Gorz 1972) ${ }^{7}$. Do jego popularyzacji przyczyniła się publikacja raportu Granice wzrostu (Meadows et al 1972), w którym pojawiła się idea zerowego wzrostu. Koncepcja odwoływała się przede wszystkim do problemu ograniczonej dostępności zasobów przyrodniczych.

O upowszechnieniu idei postwzrostu można mówić jednak dopiero w latach 90. XX w, kiedy to pojęcie zaczęło pojawiać się w tekstach różnych autorów, wśród których duże znaczenie miały prace francuskiego ekonomisty Serge'a Latouche'a (Latouche 2004; Latouche 2007; Latouche 2009a; Latouche 2009b.).

Z początkiem XXI w. rozpoczęła się dyskusja wokół relacji między postwzrostem i dyskursem zrównoważonego rozwoju. Zaczęły się również pojawiać inspirowane nim inicjatywy alternatywnego stylu życia i gospodarowania, rozwijane przez działaczy społecznych. Zarówno naukowcy, jak i działacze zainteresowali się bliżej codziennymi doświadczeniami społeczności wiejskich na globalnym Południu, przyglądając się relacjom między systemami wyznawanych wartości, działalnością człowieka a środowiskiem.

Pojawiły się też działania na poziomie instytucjonalnym. Zwolennicy postwzrostu

7 Na Gorz'a wywarły wpływ prace Nicholasa Georgescu-Roegena, uznawanego za pioniera biogospodarki, autora prawa entropii i procesu gospodarczego, opublikowanych w roku 1971. Zbiór jego artykułów ukazał się w 1979 pod tytułem Demain la décroissance (Jutro postwzrost). przede wszystkim z Francji, Hiszpanii i Włoch, a także w mniejszym stopniu z innych krajów europejskich zaczęli się organizować i spotykać na konferencjach tematycznych. Pierwszą z nich, pod hasłem Défaire le developpement, refaire le monde, zwołała w 2002 r. w Paryżu UNESCO, co zainicjowało tworzenie sojuszy między działaczami na rzecz ekologii i uczonymi zainteresowanymi postwzrostem. W organizacji następnych spotkań aktywny udział wzięła grupa badawcza Recherche \& Décroissance założona przez Francois Schneidera. Konferencje poświęcone postwzrostowi odbywały się kolejno w Paryżu (2008), Barcelonie (2010), a potem w Montrealu (2011), Wenecji (2012), Lipsku (2014), Budapeszcie (2016), Malmö (2018). Grupa naukowców z Instytutu Nauk o Środowisku i Technologii Uniwersytetu w Barcelonie (ICTA) miała szczególne znaczenie dla ruchu na rzecz postwzrostu, budując związki między działaczami a środowiskiem akademickim, zwłaszcza badaczami specjalizującymi się w dziedzinie ekonomii ekologicznej, jak również latynoamerykańskimi sieciami akademików zajmującymi się ekologią polityczną i sprawiedliwością środowiskową.

Wśród licznych autorów starających się doprecyzować pojęcie postwzrostu warto zacytować Katalończyka, Carlosa Taibó, piszącego o potrzebie „zmniejszenia produkcji i konsumpcji, ponieważ żyjemy powyżej naszych możliwości, środków, ponieważ pilnie musimy zredukować niszczące środowisko i ponieważ zaczyna brakować podstawowych surowców" (Taibó 2009: 71). Taibó podsumował program działań na rzecz postwzrostu, opierając go na sześciu filarach:

- wstrzemięźliwość i prostota;

- obrona wolnego czasu przeciwstawiająca się obsesji pracy; nowy podział pracy;

- przewaga życia społecznego nad logiką własności i nieograniczonej konsumpcji;

- zmniejszenie wymiarów infrastruktury produkcyjnej, organizacji administracyjnych i systemów transportu; 
- $\quad$ silny prymat spraw lokalnych nad globalnymi i wreszcie

- aktywna polityka redystrybucji zasobów na rzecz osób znajdujących się w niekorzystnej sytuacji przeciwstawiająca się dominującemu porządkowi kapitalistycznemu (Taibó 2009: 74-78). Większą popularność zdobył program działań proponowanych przez Serge'a Latouche'a, przede wszystkim dlatego, że sformułowany został $w$ formie ośmiu haseł rozpoczynających się - w kilku wersjach językowych - od litery R: Revalue, Recontextualize, Reestructure, Relocalize, Redistribute, Reduce, Reutilize, Recicle (Latouche 2009).

Warto odnotować, że postwzrost jest tematem rosnącej liczby opracowań naukowych. Autorzy cytowanej już książki słownika - opublikowanej w 2015 r. (D'Alisa et al 2015) piszą o ponad stu opublikowanych artykułach i co najmniej siedmiu specjalnych numerach tematycznych czasopism naukowych. Liczba publikacji jest już teraz znacznie większa. Ważną pozycją jest dossier tematyczne czasopisma „Journal of Political Ecology" nr 24. Z 2017 r. Ostatnio ukazała się książka o postwzrostowym mieszkalnictwie (Nelson, Schneider 2019). W obrębie dostępnej już literatury można wyróżnić kilka nurtów:

Jednym z pierwszych kierunków badań jest ekonomia postwzrostu. Wychodząc od krytyki koncepcji zrównoważonego rozwoju, można bronić samej koncepcji „zrównoważenia/trwałości”. Odrzucając „rozwój”, można opowiadać się za ideą zrównoważonego postwzrostu. Takie ujęcie można znaleźć w pracach Joana Martíneza Alier’a i jego współpracowników (Martinez-Alier 2009: 1099-1119; Joan Martinez-Alier et al 2010: 1741-1747) mocno podkreślających wymiar społeczny tak rozumianego postwzrostu. Niektórzy autorzy wprost mówią o tym, że „zrównoważony postwzrost oznacza postwzrost gospodarczy, który jest społecznie zrównoważony" (Bermejo et al 2010).

Tematem prac są też mechanizmy przejścia do gospodarki zrównoważonego postwzrostu, funkcjonującej w mniejszej skali, z mniejszą produkcją i konsumpcją. Wreszcie, w literaturze omawiane są też takie zagadnienia, jak znaczenie „dóbr relacyjnych” (uwaga, troska, wiedza, zaangażowanie, nowe przestrzenie wolności i duchowości etc.) (Bonaiuti 2006), zrównoważonej konsumpcji (Lorek, Fuchs, 2011: 1-8) i przedsiębiorstw społecznych w kontekście postwzrostu (Johanisova, et al 2013: 7-16).

Warto też odnotować, że postwzrost wkroczył już formalnie na scenę polityki europejskiej. We wrześniu 2018 r. dwustu naukowców z całej Europy, reprezentujących nauki społeczne i przyrodnicze, wezwała Unię Europejską, jej instytucje i kraje członkowskie do stworzenia specjalnej komisji do spraw postwzrostu w parlamencie europejskim. Miałaby się ona zająć rzetelną dyskusją na temat przyszłości wzrostu, tworzeniem alternatywnych scenariuszy post-wzrostu i krytyczną analizą utrzymywania wzrostu jako dominującego celu politycznego oraz projektowaniem działań nakierowanych na głębokie przemiany gospodarcze. „Polityki gospodarcze powinny być oceniane z perspektywy ich wpływu na jakość życia, wykorzystanie zasobów, nierówności i zapewnianie godnych miejsc pracy. Te wskaźniki powinny uzyskać wyższy priorytet niż PKB”, a Unia Europejska powinna zmienić pakt na rzecz stabilności i wzrostu w pakt na rzecz stabilności i jakości życia (web-o1).

\section{Między zrównoważonym postwzrostem a Buen Vivir}

Wspomniane na wstępie tego tekstu doświadczenia krajów latynoamerykańskich wpłynęły na zainteresowanie badaczy systemami wartości i relacjami między ludźmi i środowiskiem przyrodniczym w tradycyjnych wspólnotach wiejskich regionu, a także w tych społecznościach, które przeciwstawiają się projektom modernizacji, proponując własne wizje pożądanych zmian. Z jednej strony w Ameryce Łacińskiej możemy odnaleźć postulaty negocjacji w obrębie dyskursu nowoczesności - czyli przekonanie o możliwości konstruowania alternatywnych projektów „rozwojowych”. Za przykład mogą 
posłużyć poniższe fragmenty dokumentu stworzonego przez działaczy jednej z organizacji skupiających Afrokolumbijczyków zamieszkujących obszary położone na wybrzeżu Pacyfiku: „[To]... afirmacja prawa do odmienności, do własnej kultury, własnych społecznych form istnienia, własnej wizji życia powinna określać plany rozwoju dla społeczności Afrokolumbijskich i ich regionu. Nie mogą to być po prostu plany inwestycyjne. Chodzi raczej o instrumenty stymulujące rozwój społeczny wychodzący daleko poza rozwiązania o charakterze materialnym. Rozwój musi być skoncentrowany na ludziach, opierać się na podejmowanych przez nich decyzjach, poszerzać ludzki wymiar egzystencji. Plany rozwojowe konstruowane zgodnie z takimi założeniami wzmacniają umiejętności decyzyjne, kreatywność, solidarność, wzajemne poszanowanie, szacunek dla własnej kultury, godność, świadomość posiadania praw i własnej wiedzy. Takie procesy wzmacniać też powinny tożsamość kulturową i etniczną, poczucie związku z terytorium, na którym żyjemy. Powinny poszerzać horyzonty i tworzyć przestrzenie uczestnictwa w zmianach, przestrzenie dla wielu aktorów procesów rozwojowych" (Escobar 2008: 156). Zazwyczaj, w tego typu projekty wpisane jest myślenie kategoriami rozwoju zrównoważonego w wersji „miękkiej”, dominującej w oficjalnym dyskursie instytucjonalnym, z korektami niektórych elementów zmierzających ku wersji „twardej”.

Rozróżnienie, o którym mowa, zostało przedstawione $\mathrm{w}$ tabeli 1 na stronie 29. Pozwala na jasne zdefiniowanie sensu "zrównoważonego post wzrostu" i innych radykalnych postaw odrzucających ideę wzrostu w wymiarze materialnym i zastępujących ją takimi wartościami, jak jakość życia pojmowana w kategoriach społecznych i kulturowych oraz jakość środowiska.

Jednym z wyborów „rozwoju” jest koncepcja „dobrego życia” (Buen Vivir). Pojawiła się w Ameryce Łacińskiej pod koniec lat 90., w okresie swoistego wybuchu aktywności dużych ruchów społecznych. Choć wyrosły one na gruncie doświadczeń regionalnych, w tym m.in. rozczarowania neoliberalnym modelem rozwoju, znalazły punkty styczne z programami globalnego ruchu anty-, a potem alterglobalizacyjnego oraz zachodnich ruchów ekologicznych. Przyczyniło się do aktywnego sprzeciwu organizacji i społeczności, przede wszystkich tubylczych, wobec inicjatyw państwowych realizowanych w imię rozwoju. W odróżnieniu od postwzrostu koncepcja nie wychodzi od dekonstrukcji dominującego modelu rozwoju, ale od rodzimych wartości potwierdzających możliwość zintegrowania dobrostanu ludzi i dobrostanu przyrody. Buen Vivir to „szansa na zbudowanie nowego społeczeństwa opartego na harmonijnych i różnorodnych relacjach z przyrodą, w oparciu o zróżnicowane wartości kulturowe" (Gudynas, Acosta 2011: 103).

Choć koncepcja odwołuje się do andyjskich zasad etycznych wynikających z jedności człowieka z przyrodą, narodziła się w kręgach akademickich, które dość szybko przeniosły ją w sferę polityki. Boliwia i Ekwador wpisały Buen Vivir w teksty swych nowych konstytucji. Szybka kariera koncepcji ma wiele wspólnego z latynoamerykańską wersją podejścia postkolonialnego - określanego jako myślenie dekolonialne. Przedstawiciele tego nurtu podkreślają, że „kolonialność” Ameryki nie ograniczała się do dominacji politycznej i gospodarczej; mówią nie tylko o kolonialności władzy, lecz także o kolonialności wiedzy (dominacji naukowej, zachodniej wizji świata i wymazaniu innych rodzajów wiedzy) i kolonialności bytu (internalizacji narzuconych wyobrażeń egzystencji i negacji rodzimych koncepcji życia). Postulują dążenie do „myślenia granicznego", w obrębie którego mogłyby funkcjonować te elementy rodzime, które przetrwały do dzisiaj (Kubiaczyk 2013). Podejście dekolonialne odrzuca uniwersalizm i europocentryzm - zakłada pluralizm, w tym także pluralizm możliwych scenariuszy przyszłości. Buen Vivir wpisuje się w „myślenie graniczne” - odrzuca wzrost gospodarczy i - w odróżnieniu od 
zacytowanej propozycji kolumbijskiej - ma być polem alternatyw dla rozwoju. Władze Ekwadoru zamiast planów rozwoju kraju przygotowują „Plany dobrego życia dla jego mieszkańców", w przekonaniu, że wdrażanie zachodniego projektu nowoczesności nie przyniosło pożądanych rezultatów. W konstytucji ekwadorskiej mamy do czynienia nie tylko z prawami przysługującymi ludziom, lecz także z prawami przyrody - „dobre życie" łączy się z jej biocentryczną wizją (Gudynas 2011: 441-447). W niniejszym tekście nie ma miejsca na refleksje wokół odmiennych wersji „dobrego życia” oraz możliwości pełnej realizacji tej idei na poziomie państwa funkcjonującego w zglobalizowanym świe$\operatorname{cie}^{8}$. Z pewnością zasady harmonii między człowiekiem a przyrodą oraz założenia gospodarki wspólnotowej łatwiej wprowadzać w życie w mniejszej skali, w środowisku, któremu bliskie jest dziedzictwo kulturowe wspólnoty, w tym tradycyjne sposoby gospodarowania. Trzeba podkreślić, że „dobre życie" nie jest jednak elementem tradycji odziedziczonych po przodkach - jest konstruktem sięgającym do tych tradycji, ale wyrastającym z odrzucenia zachodniej wersji rozwoju i postępu, z poszukiwania własnych dróg wbrew dziedzictwu epoki kolonialnej, z sięgania do specyfiki zamieszkiwanego terytorium i lokalnej wiedzy na jego temat. Wszystkie te elementy możemy odnaleźć w ostatniej rubryce tabeli opisującej najsilniejszą wersję „zrównoważenia/trwałości”

\section{Zakończenie}

Cytowany kilkukrotnie Eduardo Gudynas wskazuje na to, że latynoamerykańskie Buen Vivir. „dobre życie”, i „zrównoważony postwzrost" w wersji europejskiej sporo dzieli, ale łączy je podobne, bardzo poważne pojmowanie „zrównoważenia/trwałości”.

Dla jednych obydwie koncepcje mogą stanowić ucieleśnienie ideałów rozwoju zrównoważonego/trwałego, w sensie jaki

8 Ani Ekwador, ani Boliwia nie zdołały odejść od górnictwa jako jednego z najważniejszych źródeł dochodu, choć mamy przykłady podejmowania takich prób. mu nadajemy, myśląc o wizji przyszłości dla świata. Dla innych, traktujących rozwój zrównoważony/trwały jako konkretną koncepcję obecną w dokumentach stanowiących podstawę konkretnych działań, są raczej próbami wyjścia poza dominujący paradygmat. Postulując coś więcej niż korekty czy przekształcenia obowiązującego systemu, skłaniają do myślenia o innych systemach. Uważam, że warto przyglądać się zarówno rozwojowi teoretycznych ram tych koncepcji, jak i podejmowanym w odniesieniu do nich próbom działań praktycznych. Być może w obrębie latynoamerykańskich inicjatyw transformacyjnych znajdziemy inspirację dla rozwiązań, jakich pilnie potrzebujemy w dobie kryzysu środowiskowego.

\section{Bibliografia}

Adams W., 2006, El futuro de la sostenibilidad: Repensando el medio ambiente y el desarrollo en el siglo veintiuno. [The Future of Sustainability: rethinking the environment and development in the $21^{\text {st }}$ century], Zurich: IUCN/The World Conservation Union, 20] <http://www.iucn.org/ members/ future_sustainability/> (15.01.2007).

Barcena A., Prado A., 2016, El imperativo de la igualdad. Por un desarrollo sostenible en América Latina y el Caribe [The imperative of equality. For sustainable development in Latin America and the Caribbean], Mexico, Siglo XXI Eds.

Bell K., 2014, Achieving Environmental Justice, Bristol, Policy Press.

Bermejo R., Arto I., Hoyos D., Garmendia E., 2010, Menos es más: del desarrollo sostenible al decrecimiento sostenible [Less is more: from sustainable development to sustainable degrowth], Cuadernos de Trabajo de Hegoa, No. 52.

Bonaiuti M., 2006, A la conquista de los bienes relacionales [Towards the conquest of relational goods], Colectivo Revista Silence, monográfico Objetivo Decrecimiento, Leqtor, Barcelona.

Bonevac D., 2010, Is Sustainability Sustainable, Academic Questions, 23, 84-101.

Bryant R.L., Bailey S., 1997, Third World Political Ecology, London, Routledge. 
D’Alisa Giacomo, Federico Demaria F., Giorgio Kallis (eds), 2014, Degrowth. A Vocabulary for a new era, London, Routledge.

Demaria F., Schneider F., Sekulova F., Martinez-Alier J., 2013, What is Degrowth? From an Activist Slogan to a Social Movement, Environmental Values, 22, 191-215.

Escobar A., 1995, Encountering Development. The Making and Unmaking the Third World, Princeton University Press.

Escobar A., 1999, After nature: steps to an antiessentialist political ecology, Current Anthropology, 40 (1).

Escobar A., 2008, Territories of Difference. Place, movements, life, 'redes', Duke Univeristy Press, Durham, London.

Franciszek (papież). 2016. Laudato Si'. Watykan.

Gorz Andre (M. Bosquet), 1972, Proceedings from a public debate organized in Paris by Club de Nouvelle Observateur, Nouvelle Observateur, 397, Paris, 19 June 1972.

Gudynas E., 2011, Buen Vivir: Today's tomorrow, Development, 54, 4, 441-447.

Gudynas E., 2011, Debates sobre el desarrollo y sus alternativas en América Latina: Una breve guía heterodoxa, [Debates on development and its alternatives in Latin America: a short heterodox guide] Myriam Lang i Dunia Mokrani (eds.), Más allá del Desarrollo Grupo Permanente de Trabajo sobre Alternativas al Desarrollo, Abya Yala, Quito, 21-53.

Gudynas E., 2011, Desarrollo y sustentabilidad ambiental: diversidad de posturas, tensiones permanentes, [Development and environmental sustainability: diversity of attitudes, permanent tensions] in: Mataran Ruiz A., López Catellano F. (eds.), La Tierra no es muda: dialogos entre el desarrollo sostenible y el postdesarollo, Universidad de Granada, Granada, 69-96.

Gudynas E., Acosta A., 2011, El Buen vivir o la disolución de la idea del progreso, [Good living or the dissolution of the idea of progress], in: Rojas M. (Ed.), La medición del progreso y el bienestar, Propuestas desde América Latina, Foro Consultivo Científico y Tecnológico de México, México, 103-110.

Jackson T., 2015, Dobrobyt bez wzrostu. Ekonomia dla planety o ograniczonych możliwościach, Wydawnictwo Naukowe UMK, Torun.
Johanisova N., Crabtree T., Franková E., 2013, Social enterprises and non-market capitals: a path to degrowth? Journal of Cleaner Production, 38, 7-16.

Kubiaczyk F., 2013, Nowoczesność, kolonialność i tożsamość. Perspektywa latynoamerykańska, Poznań, Wyd. UAM.

Latouche S., 2004, Sobrevivir al. desarrollo. De la descolonización del imaginario económico a la construcción de una sociedad alternativa, [Surviving development. From the decolonization of the economic imaginary to the construction of an alternative society] Editorial Icaria, Barcelona. Latouche S., 2004., Degrowth Economics, Le Monde Diplomatique, mondediplo.com/2004/11/14 latouche.

Latouche S., 2007, La otra África. Autogestión y apaño frente al mercado global, [The other Africa. Self-management and commitment within the global market] Oozebap, Barcelona.

Latouche S., 2009a, Decrecimiento y posdesarrollo. El pensamiento crítico contra la economía del absurdo. [Degrowth and postdevelopment. Critical thinking against the economy of absurdity], El Viejo Topo, España.

Latouche S., 2009b, La apuesta por el decrecimiento. Cómo salir del imaginario dominante? [The commitment to degrowth. How to get out of the dominant imaginary?], Barcelona: Icaria.

Lisocka-Jaegermann B., 2011, Kultura w rozwoju lokalnym, WGiSR UW, Warszawa.

Lisocka-Jaegermann B., 2015, Sustainable Rural Development or (Sustainable Rural Livelihoods? Strategies for the $21^{\text {st }}$ century in Peripheral Regions, Barometr Regionalny 13, 1, 13-20.

Lisocka-Jaegermann B., 2017, Del desarrollo sostenible por vulnerabilidad hacia la resiliencia? [From sustainable development, through vulnerability towards resilience] in: B. Lisocka-Jaegermann, Z. Piotrowska-Kretkiewicz, K. Ząbecki (eds.), $L a$ vulnerabilidad socioeconómica y ambiental en el contexto local y regional, WGiSR UW, Warszawa, pp. 63-73.

Lisocka-Jaegermann B., 2018, El decrecimiento como alternativa o camino a sostenibilidad? [Degrowth as an alternative or a path to sustainability?] in: M. Czerny, C. S. Mendoza (eds.), Globalización y Desarrollo Sostenible, Wyd. UW, Warszawa, S. 21-31. 
Lorek S., Fuchs D., 2011, Strong sustainable consumption governance - precondition for degrowth path?, Journal of Cleaner Production, 1-8.

Macnaughten Ph., Urry J., 2005, Alternatywne przyrody. Nowe myślenie o przyrodzie i społeczeństwie, Wydawnictwo Naukowe Scholar, Warszawa.

Martinez-Alier J., 2009, Socially Sustainable Economic Degrowth, Development and Change, 40, 6, 1099-1119.

Martinez-Alier J., Pascual U., Vivien F., Zaccai E., 2010, Sustainable de-growth: Mapping the context, criticisms and future prospects of an emergent paradigm, Ecological Economics, 69, 9, 1741-1747.

Meadows D.H., Meadows D., Rander J., Behrens W., 1972, The limits to growth, New York, Universe Books.

Nelson A., Schneider F., 2019, Housing for Degrowth: Principles, Models, Challenges and Opportunities, Routledge, Earthscan.

Peet R., Watts M., 2004, (eds), Liberation Ecologies: environment, development, social movements, London, Routledge.

Rogal H., 2010, Ekonomia zrównoważonego rozwoju. Teoria i praktyka, Zysk i S-ka, Poznań.

Sachs I., 2011, Trzeci brzeg. W poszukiwaniu ekorozwoju, Wydawnictwo UW, Warszawa.

Sachs W., 1992, The Development Dictionary. A Guide to Knowledge as Power, Zed Books London.

Schneider F., Kallis G., Martinez-Alier J., 2010, Crisis or opportunity? Economic degrowth for social equity and ecological sustainability, Introduction to this special issue, Journal of Cleaner Production, $18,511-518$.

Scoones I., 2010, Sustainability, in: D. Eade, A. Cornwall (eds.), Deconstructing Development Discourse. Buzzwords and Fuzzwords, Practical Action Pub and Oxfam GB, Warwickshire, 152-162.
Swyngedouw E., 2014, Depoliticization ('the political'), in: D'Alisa G., Demaria F., Kallis G. (eds), Degrowth: a vocabulary for a new era, Routledge, London.

Sztumski W., 2006, Idea zrównoważonego rozwoju a możliwości jej urzeczywistnienia, Problemy Ekorozwoju/Problems of Sustainable Development, $1,2,73-76$.

Sztumski W., 2008, Refleksja na temat rozwoju zrównoważonego (Czy rozwój zrównoważony jest fikcja, utopia, iluzja czy oszustwem?), Problemy Ekorozwoju/Problems of Sustainable Development, 3, 2, 133-139.

Sztumski W., 2009, Mitologia rozwoju zrównoważonego, Problemy Ekorozwoju/Problems of Sustainable Development, 4, 2, 13-23.

Szymczak Mieczysław (red.), 1992, Stownik Jezyka Polskiego, PWN, Warszawa.

Taibó C., 2009, En defensa del decrecimiento, Sobre capitalismo, crisis y barbarie [Defending degrowth. On capitalism, crisis and barbarism] Madrid, Los libros de la Catarata.

Welzer H., 2016, Samodzielne myślenie, Wydawnictwo Dobra Literatura, Słupsk.

World Commission on Environment and Development, 1987, Our Common Future, Oxford University Press, Oxford.

(Web-01) The EU needs a stability and wellbeing pact, not more growth, Guardian Letters, Sun 16 Sep 2018 https://www.theguardian.com/politics/2018/ sep/16/the-eu-needs-a-stability-and-wellbeing-pact-not-more-growth. 


\section{Sustainable development, degrowth, Buen Vivir: Voices from Latin America and Spain}

\section{Abstract}

The first part of the text deals with critical approaches to development as well as with inconsistencies and contradictions in official, institutional conceptualisations of sustainable development, as indicated by numerous representatives of critical trends. The second part is devoted to attempts to merge sustainability into a critical discourse. Differences between 'soft sustainability' in the official mainstream discourse and 'strong' and 'very strong' ones within transition initiatives developed by both academic and social activists are discussed. Examples of the latter, such as Buen Vivir and degrowth coming mainly from Spanish-speaking countries, are presented.

\section{Keywords}

development critique, sustainable development, degrowth, sustainable degrowth, transformation initiatives 